\title{
PROTECTIVE ROLE AND ANTIOXIDANT ACTIVITY OF AQUEOUS EXTRACT OF ROSMARINUS OFFICINALIS AGAINST TRICHLOROACETATE-INDUCED TOXICITY IN LIVER OF MALE RATS
}

\author{
MEDHAT MOSTAFA ABOZID ${ }^{1 *}$, HODA EA FARID ${ }^{1,2}$ \\ ${ }^{1}$ Department of Biochemistry, Faculty of Agriculture, Menoufia University, Shibin El-Kom, Egypt. ${ }^{2}$ Department of Biochemistry, Faculty of \\ Science-Al Faisaliah, King Abdulaziz University, Jeddah, Saudi Arabia. Email: medhatabozid@gmail.com
}

Received: 19 February 2018, Revised and Accepted: 27 August 2018

\section{ABSTRACT}

Objective: The current study was designed to estimate the potential protective role of the aqueous extract of rosemary (AER) (Rosmarinus officinalis) against trichloroacetic acid (TCA)-created hepatotoxicity in male albino rats.

Methods: Forty male albino rats were separated into four groups of ten: Group I served as control; Group II was given AER (200 mg/kg/day) by gavage; Group III received TCA at the dose $50 \mathrm{mg} / \mathrm{kg} /$ day, and Group IV was treated with AER (200 mg/kg/day) and received TCA (50 mg/kg/day). The experiment was carried out for 2 months.

Results: The toxicity of TCA for rats was revealed by an elevation in liver marker enzymes activities (gamma-glutamyl transferase [GGT], alkaline phosphatase [ALP], aspartate transaminase [AST], alanine aminotransferase [ALT]) and conjugated bilirubin (CB) level, and a decrease in albumin and total protein (TP) levels. The TCA administration also caused a significant increase in the activities of catalase (CAT), glutathione peroxidase (GPx) and superoxide dismutase (SOD), and also malondialdehyde (MDA) level in liver tissues. These biochemical effects were accompanied by histological indicators of liver damage. Treatment with AER recovered the liver damage instigated by TCA, as showed by perfection of liver enzyme markers (GGT, ALT, AST, ALP), CB, TP and albumin; as well as antioxidant parameters (CAT, SOD, GPx) and lipid peroxidation (MDA) and amelioration of histopathology changes in the liver tissues.

Conclusion: It could be concluded that AER supplementation for 2 months in TCA-induced toxicity in rats benefited hepatic antioxidant status and improved liver injury and damage in male albino rats exposed to TCA.

Keywords: Rosemary, Trichloroacetate, Liver marker enzymes, Antioxidant.

(c) 2018 The Authors. Published by Innovare Academic Sciences Pvt Ltd. This is an open access article under the CC BY license (http://creativecommons. org/licenses/by/4. 0/) DOI: http://dx.doi.org/10.22159/ajpcr.2018.v11i6.25353

\section{INTRODUCTION}

Liver is a very important organ in the human body because it plays an important role in growth, fighting diseases, and supplying by nutrients and energy [1]. The role of the liver is not limited to its physiological functions but extends to other important ways of protecting against the risks and side effects of drugs and various chemicals that enter the body of the organism. Despite the great advances in medical sciences, liver disease remains a major challenge throughout the world, so the search for new treatments for the liver is still underway. At present, a number of compounds derived from natural sources are used to combat various liver disorders. Therefore, many researches are looking for plant natural products to use it in protect liver cells $[2,3]$.

The presence of quantities of trichloroacetic acid (TCA) in various water sources has been detected and is also formed as a by-product during chlorination of water [4]. Various studies point to the multiplicity of sources of human exposure and are a source of TCA such as tap water, vegetables, fruits, and also cooking water $[5,6]$. In our bodies, the cytochrome P-450 enzymes are sharing reductive dechlorination for TCA, resulting in different free radicals such as reactive oxygen species (ROS) [7]. The risk of the presence of ROS is that it leads to the lipid peroxidation, which in turn oxidative damage in lipids, proteins, and DNA and eventually leads to organ toxicity [8]. Several studies have indicated that the liver is very sensitive to TCA toxicity, which causes many manifestations of liver cell damage such as; increased liver weight, changes in lipid and carbohydrate balance, liver cell cirrhosis, and hepatocyte necrosis [9-11].

Recently, it has been suggested that the use of natural foods as antioxidants, especially foods that are high in antioxidant vitamins (such as Vitamin C) as well as foods rich in phenolic compounds and flavonoids, which is characterized by its ability to fight free radicals. Rosmarinus officinalis L. which is known in English as rosemary is an evergreen plant cultivated in Egypt and many other countries across the world. It has been used in folk medicine as a medicinal plant to fight many diseases (anemia, diabetes, flu, and cold) $[12,13]$. Rosemary contains important phytochemicals which act as a natural antioxidant and anti-inflammatory agents such as rosmarinic acid, carnosol, and caffeic acid $[14,15]$. Since the rosemary plant contains many antioxidants, it protects the human body from free radicals and its harmful effects on different cells and tissues. The present study is aimed to estimate the hepatoprotective and antioxidant activity of water extract of rosemary against TCA-induced hepatotoxicity in rats. Furthermore, the phytochemical constituents and antioxidant activity of this extract were determined.

\section{METHODS}

\section{Plant material}

Fresh leaves of rosemary were collected from Haraz store for medicinal plants. The plants have been identified by the Department of Horticulture, Faculty of Agriculture, Menoufia University, Egypt.

\section{Aqueous extract preparation}

The rosemary leaves were dried under environmental temperature and powdered using a grinder. About $100 \mathrm{~g}$ of dried, ground rosemary were soaked in distilled water $(1 \mathrm{~L})$ for $72 \mathrm{~h}$ and stirred every $24 \mathrm{~h}$ by a glass rod. The final extract was filtrated through Whatman filter paper No. 1. The final filtrates were concentrated on a rotary evaporator at $40^{\circ} \mathrm{C}$ (under vacuum) then stored at $4^{\circ} \mathrm{C}$ for further use. 


\section{Chemicals and reagents}

Sodium carbonate, Folin-Ciocalteu, gallic acid, aluminum chloride, potassium acetate, quercetin, potassium ferricyanide, TCA, ferric chloride, ascorbic acid, and sodium chloride were obtained from ElGomhoria Company, Cairo, Egypt. Phenolic compounds standards, methanol and acetonitrile high-performance liquid chromatography (HPLC) grade from (Sigma) were obtained from Egyptian International Import Center, Nasr city, Egypt.

Phosphate buffer and kits of the lipid peroxidation end product malondialdehyde (MDA), catalase (CAT), superoxide dismutase (SOD), and glutathione peroxidase (GPx) were obtained from Spinreact Co., Girona (Spain) and kits for conjugated bilirubin (CB), total protein (TP), albumin and alanine aminotransferase (ALT), aspartate transaminase (AST) enzymes activity were obtained from Diamond Company, Cairo, Egypt.

\section{Antioxidant activity in vitro}

The amount of phenolic compounds in aqueous extract of rosemary (AER) was determined with Folin-Ciocalteu reagent according to Spanos and Wrolstad [16]. Aluminum chloride colorimetric method was used for flavonoids determination using the method of Aiyegoro and Okoh [17]. The reducing power of AER was determined according to Ebrahimzadeh et al. [18].

\section{Identification of phenolic compound by HPLC}

Phenolic compounds were fractionated and determined by HPLC Hewlett-Packard (series 1050) equipped with autosampling injection and ultraviolet detector set at $280 \mathrm{~nm}$ and quaternary HP pump (series 1050). A column was Alltima C18, $5 \mathrm{~mm}(150 \mathrm{~mm} \times 4.6 \mathrm{~mm})$. The column temperature was maintained at $35^{\circ} \mathrm{C}$. Gradient separation was carried out with methanol and acetonitrile as a mobile phase at flow rate of $1 \mathrm{~mL} / \mathrm{min}$. Phenolic compounds standards from Sigma Company were dissolved in a mobile phase and injected into HPLC. Retention time and peak area were used to calculate phenolic compounds concentration by the data of Hewlett-Packard software.

\section{In vivo study}

\section{Experimental animals and experimental design}

Forty male albino Wistar rats weighing between 180 and $200 \mathrm{~g}$ each were used for this experiment. They were procured from the Research Institute of Ophthalmology, Giza, Egypt.

All experimental procedures were processed according to the ethical guidelines of International Association for the Study of Pain [19]. Rats were housed in stainless steel cages placed in a well-ventilated rat house, maintained for 2 weeks as acclimatization period under standard laboratory conditions on free supply of food and water provided ad libitum and subjected to $12 \mathrm{~h}$ natural light and dark cycles. After the period of acclimatization, rats were divided randomly into four groups, 10 animals in each. The animal experiments were conducted for 2 months. Group I was received daily $0.5 \mathrm{~mL}$ of saline solution $(0.9 \% \mathrm{NaCl})$ orally for 2 months and was used as control group (CG); Group II was administrated orally with AER (200 mg/kg body weight) by gavage reperfusion group (RG); Group III was received TCA at dose $50 \mathrm{mg} / \mathrm{kg} /$ day triglycerides (TG); Group IV was received the rosemary (200 mg/kg/day) and receive TCA at dose $50 \mathrm{mg} / \mathrm{kg} /$ day radioisotope thermoelectric generator (RTG).

Hepatoprotective activity was calculated according to the formula of Singh et al. [20].

Hepatoprotective activity $(\%)=1-[(\mathrm{RTG}-\mathrm{CG}) /(\mathrm{TG}-\mathrm{CG})] \times 100$

\section{Serum collection and tissue preparation}

The rats were anesthetized and sacrificed after the examination period (2 months), the blood samples were collected from a cardiac puncture and put immediately into glass tubes and centrifuged at $3000 \mathrm{rpm}$ for $20 \mathrm{~min}$ at $4^{\circ} \mathrm{C}$ to separate serum samples which stored in aliquots at $-20^{\circ} \mathrm{C}$ till used. The livers were immediately removed, washed with normal saline solution $(0.9 \%, \mathrm{w} / \mathrm{v})$, blotted, and weighed. Small pieces were fixed in $10 \%$ neutral buffered formalin for routine histopathology, and the remaining part was homogenized in ice-cold Tris-buffered saline, $\mathrm{pH} 7.4$, and centrifuged at $3000 \mathrm{rpm}$ for $10 \mathrm{~min}$ at $4^{\circ} \mathrm{C}$. The homogenate was collected in aliquots, stored at $-20^{\circ} \mathrm{C}$ until use.

\section{Measurement of biochemical parameters}

Serum AST and ALT activities were determined according to Reitman and Frankel [21]. CB level and alkaline phosphatase (ALP) activity were determined according to Malloy and Evelyn and Kind and King $[22,23]$, respectively. Serum TP level was determined by Biuret method Lubran [24] while that of albumin level was determined by bromocresol green according to Waterborg [25]. The lipid peroxidation end product MDA level was measured according to Ohkawa et al. [26]. Furthermore, CAT activity was determined as described by Aebi [27], SOD activity was measured using the method of Nishikimi et al. [28] and kinetic determination of GPx activity was done according to the method of Paglia and Valentine [29].

\section{Histopathology of the rat livers}

The liver tissues prepared for histopathological examination by light microscope according to the method of Carleton [30], through the following steps: First, dehydration using serial dilutions of methyl and absolute ethyl alcohols, second, samples embedded in paraffin, third prepared paraffin bees wax tissue blocks and sectioned at $4 \mu$ by sledge microtome, and finally tissue sections were collected on glass slides, deparaffinized and stained by hematoxylin and eosin stains.

\section{Statistical analysis}

The values were expressed as mean \pm standard deviation. The data were analyzed by one-way analysis of variance and Student's t-tests using the SPSS Version 11.5. $\mathrm{p} \leq 0.05$ was considered statistically significant.

\section{RESULTS}

\section{Phytochemical and antioxidant activity of AER}

Phytochemical analysis using HPLC and spectrophotometric assays provided qualitative insights the bioactive components of AER. Table 1 shows AER containing $18 \mathrm{mg}$ gallic acid equivalents/100 g dry matter (DM) of total phenolics content and $8.6 \mathrm{mg}$ quercetin equivalent/100 g DM of total flavonoids content.

A total of six phenolic compounds (caffeic acid, ferulic acid, apigenin, luteolin, gallic acid, and gallic acid methyl ester) were characterized by HPLC. Luteolin and caffeic acid were present in high levels (3.96 and $3.24 \mathrm{mg} / 100 \mathrm{~g}$ DM, respectively). Traces of ferulic acid, apigenin, gallic acid, and gallic acid methyl ester were also detected.

Fig. 1 showed the dose-response curves for the reducing powers of the AER compared with ascorbic acid; the reducing powers of AER increased by increasing the extract concentration. At the highest concentration $(800 \mu \mathrm{g} / \mathrm{mL})$, AER showed highest activity (0.856). Fig. 1 also indicates that Vitamin $\mathrm{C}$ has a higher reducing power than the AER at all concentrations.

\section{Effects of TCA on biochemical liver markers}

The results tabulated in Table 2 revealed that the treatment with TCA in TG induced a significant increase in serum enzyme activities of ALT, AST, and ALP as compared with normal rats (CG); while the treatment only with AER (RG) did not cause any significant changes compared with CG. Treatment with AER in rats treated with TCA in drinking water RTG allowed these parameters to significantly reduce and come near the CG values. In another way, the supplementation with TCA (TG) increased the levels of CB and reduction the albumin TP levels as compared with CG; however, supplementation with ARE moderated these alterations and reestablished it close to the normal values for control rats or those supplemented with AER only.

Expressed in percentage of liver protection provided, AER was hepatoprotective as calculated by the formula of Singh et al. [20]. Fig. 2 presents the results of our calculations of liver protection as provided 
by AER in TCA-induced hepatotoxicity in rats. Fig. 2 showed the ratio of protection resulting from treatment with AER on each of the AST (21.09\%), ALT (56.1\%), ALP (52.56\%), and CB (46.08\%).

\section{Enzymatic antioxidant status and MDA levels in liver}

Rats in TG (treated with TCA) showed a significant increase in SOD, CAT, and GPx activities as compared with CG (Table 3). TCA also induced a significant elevation in the MDA content in liver tissues as compared with CG. Oral supplementation with $200 \mathrm{mg} / \mathrm{kg} /$ day of AER against TCA treatment (RTG) caused a significant decreased in all antioxidant enzymes (SOD, CAT, and GPx) activities compared with rats treated with TCA only (TG). Moreover, AER regulation alleviated lipid peroxidation prompted by TCA treatment and significantly improved MDA levels in liver (Table 3).

\section{Histopathology of rat liver tissue}

Microscopic screening of the liver in CG and RG groups showed normal structure and cellular architecture for liver cells (Fig. 3a and b). In contrast, supplementation of TCA for 2 months prompted damage to the liver cells with disarrangement of liver strands. The liver sections in TG group showed vacuolation of hepatocytes with hydropic degeneration (Fig. 3c). However, treatment with AER (RTG) has greatly improved the deterioration of liver cells (Fig. 3d). Based on the liver histopathological changes, we can confirm that the treatment of TCA caused hepatotoxicity, while the water extract of rosemary showed a protective effect against this toxicity, resulting in liver cell protection.

\section{DISCUSSION}

Hepatotoxicity has been specified as the most notable effect of TCA that are created in rodents [31,32].

The hepatotoxicity resulting from TCA treatment can be explained by the production of ROS, which have been observed to increase in

Table 1: Phytochemical composition of AER

\begin{tabular}{ll}
\hline Phytochemical parameters & Amounts \\
\hline TPC mg GAE/100 g DM & $18 \pm 0.53$ \\
TFC mg QE/100 g DM & $8.6 \pm 0.22$ \\
Polyphenolic compounds (mg/100 g DM) & \\
Luteolin & $3.96 \pm 0.01$ \\
Caffeic acid & $3.24 \pm 0.06$ \\
Apigenin & $0.81 \pm 0.03$ \\
Ferulic acid & $0.684 \pm 0.07$ \\
Gallic acid & $0.378 \pm 0.02$ \\
Gallic acid methyl ester & $0.306 \pm 0.04$ \\
\hline
\end{tabular}

Data are reported as the mean $\pm S D$ of three replicates. AER: Aqueous extract of rosemary, TPC: Total phenolics content, GAE: Gallic acid equivalents, DM: Dry matter, TFC: Total flavonoids content, QE: Quercetin equivalent, SD: Standard deviation

Table 2: Effect of aqueous rosemary extract on serum liver functions in different groups

\begin{tabular}{lllll}
\hline \multicolumn{1}{l}{ Groups } & \multicolumn{1}{l}{ CG } & RG & TG & RTG \\
\cline { 1 - 5 } Parameters & & & & \\
\hline AST (U/l) & $17.92 \pm 1.43 \mathrm{a}$ & $18.17 \pm 1.36 \mathrm{a}$ & $41.25 \pm 1.5 \mathrm{c}$ & $36.33 \pm 1.4 \mathrm{~b}$ \\
ALT (U/l) & $33.17 \pm 1.37 \mathrm{a}$ & $35.25 \pm 2.42 \mathrm{a}$ & $53.67 \pm 1.08 \mathrm{c}$ & $42.17 \pm 1.5 \mathrm{~b}$ \\
ALP (U/l) & $113.08 \pm 2.3 \mathrm{a}$ & $114.7 \pm 2.09 \mathrm{a}$ & $134.2 \pm 1.72 \mathrm{c}$ & $123.1 \pm 2.5 \mathrm{~b}$ \\
CB (mg/dl) & $0.423 \pm 0.02 \mathrm{a}$ & $0.427 \pm 0.03 \mathrm{a}$ & $0.64 \pm 0.025 \mathrm{c}$ & $0.54 \pm 0.02 \mathrm{~b}$ \\
TP (g/dl) & $6.21 \pm 0.89 \mathrm{c}$ & $6.24 \pm 0.75 \mathrm{c}$ & $4.85 \pm 0.29 \mathrm{a}$ & $5.34 \pm 0.3 \mathrm{~b}$ \\
Albumin & $4.19 \pm 0.11 \mathrm{c}$ & $4.22 \pm 0.13 \mathrm{c}$ & $3.73 \pm 0.08 \mathrm{a}$ & $4.06 \pm 0.07 \mathrm{~b}$
\end{tabular}

$(\mathrm{g} / \mathrm{dl})$

Data are expressed as means \pm SD (n=10 rats per group). Comparison between groups was made using Student's t-tests. Values in the same columns not sharing a common letter $(\mathrm{a}-\mathrm{c})$ differ significantly at $\mathrm{P}<0.05$. AST: Aspartate transaminase, ALT: Alanine aminotransferase, ALP: Alkaline phosphatase, CB: Conjugated bilirubin, TP: Total protein, CG: Control group, RG: Aqueous extract of rosemary group, TG: TCA group, RTG: Aqueous extract of rosemary + TCA group the liver tissues of mice treated with TCA $[8,33,34]$. Dietary intake of different plant extracts (which contain polyphenolics and flavonoids) grants repressing effects versus oxidative damage in animals [35] and humans [36]. In this context, the current study affirms that AER modulates significantly the liver functions against the harmful effects of TCA.

Our results showed that AER was rich in total phenolic compounds and total flavonoids (Table 1 ) that contributed to its antioxidant activity to scavenge free radicals. This result is in harmony with many authors $[12,37,38]$ who found that rosemary is rich in different phenolic compounds and flavonoids. There is a close relationship between the reducing power and the antioxidant activity of the various extracts, which is considered to be an expression of the efficacy of these extracts as antioxidants [39]. In this study, main polyphenolic compound in AER was luteolin $(3.96 \pm 0.01 \mathrm{mg} / 100 \mathrm{~g} \mathrm{DM})$ which showed high antioxidant activity when tested by reducing power assay compared with butylated hydroxytoluene [40]. Flavonoids with a hydroxyl group in their structure (such as luteolin) have antioxidant properties as they donate hydrogen to a free radical [41]. On the other hand, the second important phenolic compound in AER is caffeic acid $(3.24 \pm 0.06 \mathrm{mg} / 100 \mathrm{~g} \mathrm{DM})$ which also showed high antioxidant activity because of caffeic acid has two hydroxyl groups and therefore has good antioxidant properties [42]. The antioxidant effect of AER may be related to its various phenolic compounds content, which is characterized by redox properties, making them act as hydrogen donor, and put out singlet oxygen radicals [43].

Table 3: Effects of rosemary aqueous extract on the activity of SOD, CAT, GPX, and MDA content in rat liver in different groups

\begin{tabular}{|c|c|c|c|c|}
\hline Groups & CG & RG & TG & RTG \\
\hline \multicolumn{5}{|c|}{ Parameters } \\
\hline $\begin{array}{l}\text { SOD } \\
\text { (U/mg } \\
\text { protein) }\end{array}$ & $19.42 \pm 2.01 \mathrm{a}$ & $18.47 \pm 1.92 \mathrm{a}$ & $41.75 \pm 2.2 \mathrm{c}$ & $31.58 \pm 2.6 b$ \\
\hline $\begin{array}{l}\text { CAT } \\
\text { (U/mg } \\
\text { protein) }\end{array}$ & $91.83 \pm 1.8 \mathrm{a}$ & $89.42 \pm 2.85 a$ & $118.4 \pm 3.2 \mathrm{c}$ & $102.9 \pm 1.9 b$ \\
\hline $\begin{array}{l}\text { GPx } \\
\text { (U/mg } \\
\text { protein) }\end{array}$ & $14.87 \pm 1.73 \mathrm{a}$ & $15.17 \pm 2.32 \mathrm{a}$ & $32.83 \pm 1.78 c$ & $21.85 \pm 1.6 b$ \\
\hline $\begin{array}{l}\text { MDA } \\
\text { (nmol/g } \\
\text { tissue) }\end{array}$ & $45.08 \pm 2.46 \mathrm{a}$ & $44.75 \pm 2.83 \mathrm{a}$ & $76.67 \pm 1.72 \mathrm{c}$ & $60.5 \pm 1.45 b$ \\
\hline
\end{tabular}

Data are expressed as means \pm SD ( $n=10$ rats per group). Comparison between groups was made using Student's t-tests. Values in the same columns not sharing a common letter $(\mathrm{a}-\mathrm{c})$ differ significantly at $\mathrm{P}<0.05$. SD: Standard deviation, SOD: Superoxide dismutase, CAT: Catalase, GPx: Glutathione peroxidase, MDA: Malondialdehyde, CG: Control group, RG: Aqueous extract of rosemary group, TG: TCA group, RTG: Aqueous extract of rosemary + TCA group

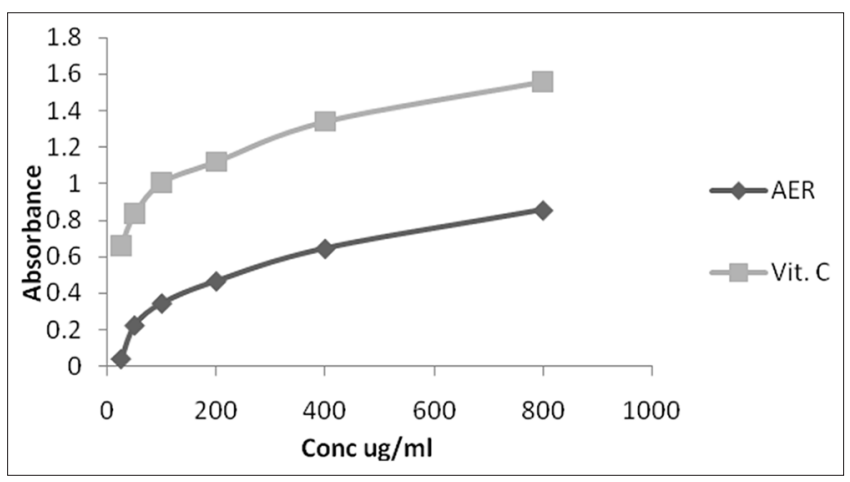

Fig. 1: Reducing ability of aqueous extract of rosemary compared with ascorbic acid at various concentrations 


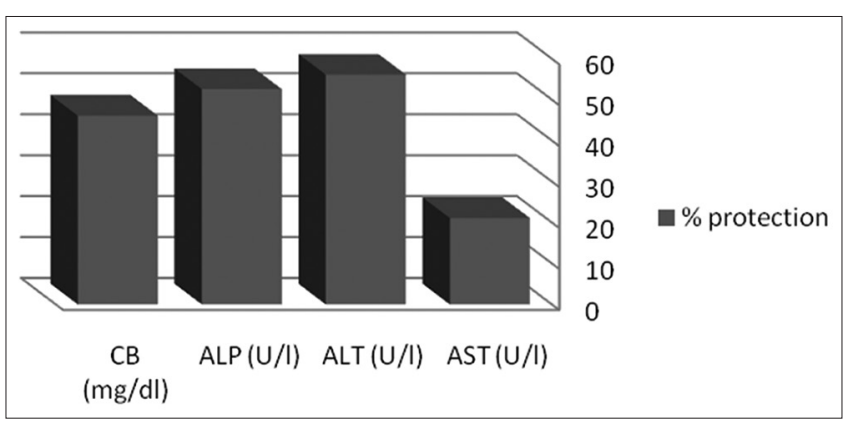

Fig. 2: Hepatoprotective activity of aqueous extract of rosemary in trichloroacetic acid-induced hepatotoxicity in rats. Data are expressed as means \pm standard deviation ( $\mathrm{n}=10$ rats per group). Comparison between groups was made using Student's t-tests at p $<0.05$
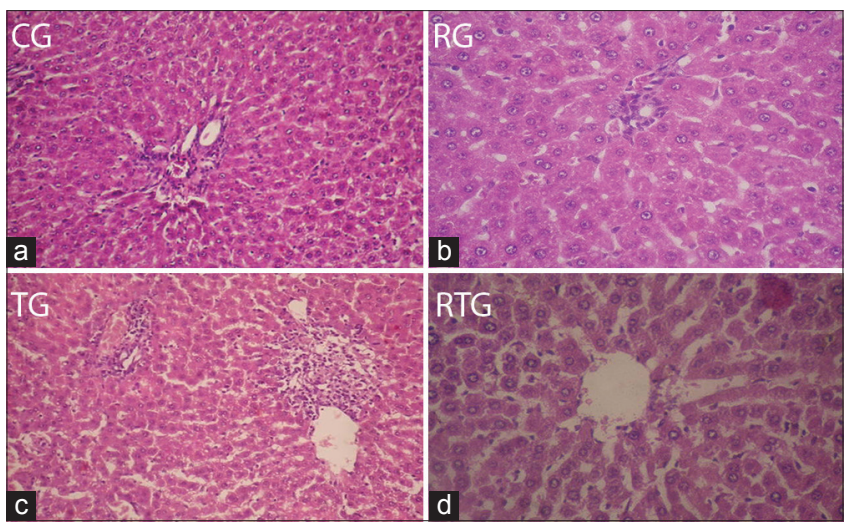

Fig. 3: Liver histopathology in different groups. (a) Control group showed hepatic lobules showing central veins surrounded by columns of normal hepatocytes having abundant eosinophilic

cytoplasm, central rounded nuclei separated by blood sinusoids; (b) reperfusion group showed normal histological structure, mild hydropic degeneration, hepatocytes were rounded with granular eosinophilic cytoplasm with central rounded nuclei; (c) triglycerides showed central vein congestion, hepatocytes were rounded with granular eosinophilic cytoplasm with central rounded nuclei; (d) radioisotope thermoelectric generator showed mild tubular necrosis with regenerated tubular cells ( $H$ and $E, \times 40$ )

The treatment with TCA ( $0.5 \mathrm{~g} / \mathrm{L}$ in drinking water) caused liver enzymes (ALT, AST, and ALP) to exit from the liver cells into bloodstream; it also results in lower levels of albumin in serum, which is consistent with the recognition that TCA is a known hepatotoxin that is used extensively for the induction of hepatotoxicity in animal models [44]. The occurrence of these changes in the biochemical evidence is a strong indicator of significant malfunction in the various liver functions [45]. In the present study, oral treatments with $200 \mathrm{mg} / \mathrm{kg}$ /day of AER for 60 days significantly reversed the altered serum liver function parameters in the TCA-treated rats. The hepatoprotective effects of AER can be linked to the phenolic compounds and flavonoids, which are characterized by an antioxidant activity; that can fight the oxidative stress caused by TCA [46-49].

The biochemical biomarkers of liver functions in serum supported the histopathological damages in liver cells in the current work. These observations confirmed significant histological changes in the liver cells as a result of TCA treatment. It might be due to its toxic impact by the generation of free radicals causing destroy to the various membrane components of the liver cells. Similar results have been recorded in previous studies, which have led to significant histopathological changes in liver cells as a result of the treatment of TCA [50].
On measuring free radical-induced oxidative stress, enzyme markers such CAT, SOD, GPx, and for lipid peroxidation, catabolite such as MDA are widely accepted and used [51]. To evaluate the effect of AER on TCAinduced oxidative stress and activities of antioxidant enzymes CAT, SOD, $\mathrm{GPx}$, and MDA level were measured.

The present study showed that TCA induced a significant increase in the activity of SOD, CAT, and GPx compared with normal CG; these results are agreement with El Arem et al.; Hassoun and Cearfoss [52,53], who confirmed the increase in these enzymes activity in the serum when animals treated with TCA. TCA treatment resulted in an increase in SOD and CAT activities suggesting a partial role of SOD-CAT in protection against cellular toxicity and the contribution of superoxide anion and $\mathrm{H}_{2} \mathrm{O}_{2}$ to the previously observed oxidative cellular damage associated with TCA treatment [53].

In rats treated with AER and TCA (RTG), we found that the activities of these enzymes have returned to approximate the normal values of the CG.

Levels of MDA in different tissues are a primary indicator of the degree of lipid peroxidation as it is the final product of polyunsaturated fatty acid peroxidation. Our results showed that the liver content of MDA was significantly elevated in TCA-treated rats. This elevation might have resulted from an elevation of ROS as a result of the stressful conditions in the rats exposed to TCA. The significant decreased of MDA levels in rats treated with AER (RTG) may be due to inhibitory action of this extract on lipid peroxidation that may be related by the antioxidant activity which helps in the protection of membrane integrity.

The ability of the AER to recover SOD, CAT, and GPx activities and MDA levels to normal levels of animals treated with TCA might be attributed to antioxidant properties and the free radical scavenging of rosemary aqueous extract since antioxidants appear to confront disease by increasing the activities of antioxidant enzymes and reduced lipid peroxidation [54].

Thus, this results strongly further suggests antilipoperoxidation activity of AER. The antioxidant activity and hepatoprotective effect of AER could be attributed to its high content from phenolic compounds and flavonoids as these phytocomponents have been widely reported to possess antioxidant and antilipoperoxidative activities [55].

\section{CONCLUSION}

The present study suggests that AER has a potent antioxidant and hepatoprotective activity in TCA-induced hepatic injury in rats. Rosemary may possess both antioxidant and antilipoperoxidative activities by inhibiting and scavenging free radicals generated by TCA. These findings provide biochemical and histological data supporting folkloric use of rosemary in the local treatment of some hepatic disorders.

\section{AUTHORS' CONTRIBUTIONS}

Medhat M. Abozid developed the design of the experiment, carried out the biological experiment, and analyzed the results. Hoda E.A. Farid shared in the design and implementation of the experiments and did statistical analysis and wrote the manuscript.

\section{COMPETING INTERESTS}

The authors declare that there is no conflict of interests regarding the publication of this paper.

\section{REFERENCES}

1. Ward FM, Daly MJ. Hepatic Disease in Clinical Pharmacy and Therapeutics. $1^{\text {st }}$ ed. New York: Churchill Livingston; 1999. p. 195- 212.

2. Roy SD, Das S, Di S, Dutta KN. Herbal hepatoprotective agents. World J Pharm Res 2012;1:87-99.

3. Zhang A, Sun H, Wang X. Recent advances in natural products from plants for treatment of liver diseases. Eur J Med Chem 2013;63:570-7. 
4. Coleman W, Melton R, Kopfler F, Barone K, Aurand T, Jellison M. Identification of organic compounds in a mutagenic extract of a surface drinking water by a computerized gas chromatography/mass spectrometry system (GC/MS/COM). Environ Sci Technol 1980;14:576-88.

5. Reimann S, Grob K, Frank H. Chloroacetic acids in rainwater. Environ Sci Technol 1996;30:2340-4.

6. Schroll R, Bierling B, Cao G, Dorfler U, Lahaniati M, Langenbach T, et al. Uptake pathways of organic chemicals from soil by agricultural plants. Chemosphere 1994;28:297-303.

7. Larson JL, Bull RJ. Metabolism and lipoperoxidative activity of trichloroacetate and dichloroacetate in rats and mice. Toxicol Appl Pharmacol 1992;115:268-77.

8. Austin EW, Parrish JM, Kinder DH, Bull RJ. Lipid peroxidation and formation of 8-hydroxydeoxyguanosine from acute doses of halogenated acetic acids. Fundam Appl Toxicol 1996;31:77-82.

9. DeAngelo AB, Daniel FB, McMillan L, Wernsing P, Savage RE Jr. Species and strain sensitivity to the induction of peroxisome proliferation by chloroacetic acids. Toxicol Appl Pharmacol 1989;101:285-98.

10. Bhat HK, Ahmed AE, Ansari GA. Toxicokinetics of monochloracetic acid: A whole-body autoradiography study. Toxicology 1991;63:35-43.

11. Mather GG, Exon JH, Koller LD. Subchronic 90 day toxicity of dichloroacetic and trichloroacetic acid in rats. Toxicology 1990;64:71- 80.

12. Al-Sereiti MR, Abu-Amer KM, Sen P. Pharmacology of rosemary (Rosmarinus officinalis linn.) and its therapeutic potentials. Indian $\mathrm{J}$ Exp Biol 1999;37:124-30.

13. Ugulu I, Baslar S, Yorek N, Dogan Y. The investigation and quantitative ethnobotanical evaluation of medicinal plants used around Izmir province. Turk J Med Plants Res 2009;3:345-67.

14. Afonso MS, Sant'Ana LS. Effects of pretreatment with rosemary (Rosmarinus officinalis L.) in the prevention of lipid oxidation in salted tilapia fillets. J Food Qual 2008;31:586-95.

15. Pérez-Fons L, Garzón MT, Micol V. Relationship between the antioxidant capacity and effect of rosemary (Rosmarinus officinalis L.) polyphenols on membrane phospholipid order. J Agric Food Chem 2010;58:161-71.

16. Spanos GA, Wrolstad RE. Influence of processing and storage on the phenolic composition of Thompson seedless grape juice. J Agric Food Chem 1990;38:1565-71

17. Aiyegoro OA, Okoh AI. Preliminary phytochemical screening and in vitro antioxidant activities of the aqueous extract of Helichrysum longifolium DC. BMC Complement Altern Med 2010;10:21.

18. Ebrahimzadeh MA, Pourmorad F, Hafezi S. Antioxidant activities of Iranian corn silk. Turk J Biol 2008;32:43-9.

19. Zimmermann M. Ethical guidelines for investigations of experimental pain in conscious animals. Pain 1983;16:109-10.

20. Singh B, Saxena AK, Chandan BK, Anand KK, Suri OP, Suri KA, et al. Hepatoprotective activity of verbenalin on experimental liver damage in rodents. Fitoterapia 1998;69:135-40.

21. Reitman S, Frankel S. Glutamic-pyruvate transaminase assay by colorimetric method. Am J Clin Path 1957;28:56.

22. Kind PR, King EJ. Determination of serum alkaline phosphatase. J Clin Path 1954;7:132-6.

23. Malloy HT, Evelyn KA. The determination of bilurubin with the photoelectric colorimeter. J Biolog Chem 1937;119:481-5

24. Lubran MM. The measurement of total serum proteins by the biuret method. Ann Clin Lab Sci 1978;8:106-10.

25. Waterborg JH. The Lowry method for protein quantitation. In: Protein Protocols Handbook. $2^{\text {nd }}$ ed. New Jersey: Humana Press; 2002. p. 7-9.

26. Ohkawa H, Ohishi N, Yagi K. Assay for lipid peroxides in animal tissues by thiobarbituric acid reaction. Anal Biochem 1979;95:351-8.

27. Aebi HE. Catalase. In: Bergmeyer HU, editor. Methods of Enzymatic Analysis. New York: Verlag Chemie Weinhem Press; 1983. p. 273-86.

28. Nishikimi M, Roa NA, Yogi K. Measurement of superoxide dismutase. Biochem Biophys Res Common 1972;46:849-54.

29. Paglia DE, Valentine WN. Studies on the quantitative and qualitative characterization of erythrocyte glutathione peroxidase. J Lab Clin Med 1967;70:158-69.

30. Carleton H. Carleton's histological technique. Ulster Med J 1967;36:172.

31. Bull RJ, Sanchez IM, Nelson MA, Larson JL, Lansing AJ. Liver tumor induction in $\mathrm{B} 6 \mathrm{C} 3 \mathrm{~F} 1$ mice by dichloroacetate and dichloroacetate. Toxicology 1990;63:341-59.

32. Daniel FB, DeAngelo AB, Stober JA, Olson GR, Page NP. Hepatocarcinogenicity of chloral hydrate, 2-chloroaldehyde and dichloroacetic acid in the male B6C3F1 mouse. Fundam Appl Toxicol 1992; 19:159-68.
33. Hassoun EA, Dey S. Dichloroacetate- and trichloroacetate-induced phagocytic activation and production of oxidative stress in the hepatic tissues of mice after acute exposure. J Biochem Mol Toxicol 2008:22:27-34.

34. Parrish JM, Austin EW, Stevens DK, Kinder DH, Bull RJ. Haloacetateinduced oxidative damage to DNA in the liver of male B6C3F1 mice. Toxicology 1996;110:103-11.

35. Abozid MM, EL-Sayed SM. Antioxidant and protective effect of clove extracts and clove essential oil on hydrogen peroxide-treated rats. Int J Chem Tech Res 2013;5:1477-85.

36. Liu RH. Health benefits of fruits and vegetables are from additive and synergistic combination of phytochemicals. Am J Clin Nutr 2003; 78:517S-20S

37. Zhang Y, Smuts JP, Dodbiba E, Rangarajan R, Lang JC, Armstron DW, et al. Degradation study of carnosic acid, carnosol, rosmarinic acid, and rosemary extract (Rosmarinus officinalis L.) assessed using HPLC. J Agric Food Chem 2012;60:9305-14.

38. Hossain MB, Rai DK, Brunton NP, Martin-Diana AB, Barry-Ryan C. Characterization of phenolic composition in Lamiaceae spices by LCESI-MS/MS. J Agric Food Chem 2010;58:10576-81.

39. Oktay M, Gulcin I, Kufrevioglu OI. Determination of in vitro antioxidant activity of fennel (Foeniculum vulgare) seed extracts. Lebensum Wiss U Technol 2003;36:263-71.

40. Alesheikha P, Feyzia P, Kamalib M, Sania TA. Evaluation of antioxidant activity of Luteolin, isolated from Dracocephalum kotschyi. J Med Plant Nat Prod 2016;1:41-7.

41. Miliauskas G, Venskutonis P, Van Beek T. Screening of radical scavenging activity of some medicinal and aromatic plant extracts. Food Chem 2004;85:231-7.

42. Masek A, Chrzescijanska E, Latos M. Determination of antioxidant activity of caffeic acid and p-coumaric acid by using electrochemical and spectrophotometric assays. Int J Electrochem Sci 2016;11:10644- 58.

43. Negri G, Teixeira EW, Alves ML, Moreti AC, Otsuk IP, Borguini RG, et al. Hydroxycinnamic acid amide derivatives, phenolic compounds and antioxidant activities of extracts of pollen samples from Southeast Brazil. J Agric Food Chem 2011;59:5516-22.

44. Richardson SD, Thruston AD, Krasner SW, Weinberg HS, Miltner RJ, Schenck KM, et al. Integrated disinfection byproducts mixtures research: Comprehensive characterization of water concentrates prepared from chlorinated and ozonated/postchlorinated drinking water. J Toxicol Environ Health A 2008;71:1165-86.

45. Rajesh MG, Latha MS. Preliminary evaluations of the antihepatotoxic effect of Kamilari, a polyherbal formulation. J Ethnopharmacol 2004;91:99-104.

46. Lee HJ, Cho HS, Park E, Kim S, Lee SY, Kim CS, et al. Rosmarinic acid protects human dopaminergic neuronal cells against hydrogen peroxide-induced apoptosis. Toxicology 2008;250:109-15.

47. Al-Harbi MS. Hepatoprotective effect and antioxidant capacity of naringenin on arsenic-induced liver injury in rats. Int J Pharm Pharm Sci 2016;8:103-8.

48. EL-Gengaihi SE, Hamed MA, Aboubaker DH, Mossa AH. Flavonoids from sugar beet leaves as hepatoprotective agent. Int J Pharm Pharm Sci 2016;8:281-6.

49. Panuganti SD, Khan FD, Svensson CK. Enhanced xenobioticinduced hepatotoxicity and kupffer cell activation by restraint-induced stress. J Pharmacol Exp Ther 2006;318:26-34.

50. Acharya S, Mehta K, Rodriguez S, Pereira J, Krishnan S, Rao CV, et al. A histopathological study of liver and kidney in male wistar rats treated with subtoxic doses of t-butyl alcohol and trichloroacetic acid. Exp Toxicol Pathol 1997;49:369-73.

51. Celik I. Determination of toxicity of trichloroacetic acid in rats: 50 days drinking water study. Pestic Biochem Phys 2007;89:39-45.

52. El Arem A, Saafi EB, Ghrairi F, Thouri A, Zekri M, Ayed A, et al. Aqueous date fruit extract protects against lipid peroxidation and improves antioxidant status in the liver of rats subchronically exposed to trichloroacetic acid. J Physiol Biochem 2014;70:451-64.

53. Hassoun EA, Cearfoss J. Dichloroacetate- and trichloroacetateinduced modulation of superoxide dismutase, catalase, and glutathione peroxidase activities and glutathione level in the livers of mice after subacute and subchronic exposure. Toxicol Environ Chem 2011;93:332- 44

54. Bansal AK, Bansal M, Soni G, Bhatnagar D. Protective role of vitamin $\mathrm{E}$ pre-treatment on $\mathrm{N}$-nitrosodiethylamine induced oxidative stress in rat liver. Chem Biol Interact 2005;156:101-11.

55. Khalil OA, Ramadan KS, Danial EN, Alnahdi HS, Ayaz NO. Antidiabetic activity of Rosmarinus officinalis and its relationship with the antioxidant property. Afr J Pharm Pharmacol 2012;6:1031-6. 